\title{
KARAKTERISTIK PEMBAKARAN BIOBRIKET CAMPURAN BATUBARA, AMPAS TEBU DAN JERAMI
}

\author{
Subroto \\ Jurusan Teknik Mesin Fakultas Teknik Universitas Muhammadiyah Surakarta \\ Jl.A.Yani Tromol Pos 1 Pabelan Kartasura
}

\begin{abstract}
ABSTRAK
Potensi biomass ampas tebu dan jerami sebagai sumber energi alternatif sedemikian melimpah, namun belum terolah sepenuhnya. Berawal dari hal tersebut maka peneliti mengajukan penelitian mengenai pengolahan biomass ampas tebu dan jerami dengan campuran batubara serta bahan perekat yang terbuat dari tepung pati guna diolah menjadi bahan bakar alternatif berupa biobriket. Dalam penelitian ini komposisi yang di uji adalah biobriket dengan perbandingan prosentase batubara : biomass (ampas tebu dan jerami); $10 \%$ : $90 \% ; 33,3 \%$ : 66,6\% ; 50\% : 50\% . Penelitian awal dilakukan dengan pengumpulan, penghalusan, pengujian bahan baku (kadar air, nilai kalor, kadar abu, volatile matter, kadar karbon) dan pencampuran bahan baku (batu bara, ampas tebu, jerami dan perekat pati), selanjutnya dilakukan pengepresan dengan tekanan $100 \mathrm{~kg} / \mathrm{cm}^{2}$. Pengujian pembakaran dilakukan di laboratorium untuk mengetahui besarnya laju pengurangan massa dengan laju kecepatan udara konstan $(0,3 \mathrm{~m} /)$, kemudian dilanjutkan dengan pengujian emisi polutan . Berdasarkan percobaan dan parameter yang telah di uji, penambahan biomass menyebabkan naiknya volatile matter sehingga lebih cepat terbakar dan laju pembakaran lebih cepat. Penambahan biomass juga dapat menurunkan emisi polutan yang dihasilkan pada saat pembakaran. Komposisi biobriket terbaik yang dapat digunakan untuk kebutuhan sehari-hari adalah komposisi batubara 10\% : biomass 90\% karena lebih cepat terbakar, suhu yang dicapai dapat optimal dan lebih ramah lingkungan.
\end{abstract}

Kata kunci : Batubara, ampas tebu dan jerami.

\section{PENDAHULUAN}

Seperti yang telah diketahui, minyak bumi adalah sumber energi yang tidak dapat diperbarui, tetapi dalam kehidupan seharihari bahan bakar minyak masih menjadi pilihan utama sehingga dapat mengakibatkan menipisnya cadangan minyak bumi. Sementara batubara dan gas bumi belum dimaksimalkan pemanfaatannya untuk konsumsi dalam negeri. Sesungguhnya negara Indonesia mempunyai potensi yang luar biasa mengenai sumber-sumber daya energi alternatif.

Beberapa energi alternatif yang bisa dikembangkan sebagai pengganti dari minyak bumi adalah gas bumi, batubara dan biomass. Untuk gas bumi dan batubara masih merupakan energi fosil tetapi belum dimaksimalkan pemakaiannnya, berdasarkan hal tersebut peneliti berfikir untuk memanfaatkan sumber energi alternatif baru. Biomassa merupakan bahan alami 
yang biasanya dianggap sebagai sampah dan sering dimusnahkan dengan cara dibakar. Biomassa tersebut dapat diolah menjadi bioarang, yang merupakan bahan bakar dengan tingkat nilai kalor yang cukup tinggi dan dapat digunakan dalam kehidupan sehari-hari.

Limbah pertanian yang selama ini merupakan masalah umum didaerah pedesaan dan sering menimbulkan permasalahan, karena menjadi satu penyebab pencemaran lingkungan. Sebagai contohnya adalah ampas tebu dan jerami.

Ampas tebu adalah hasil samping dari proses ekstraksi (pemerahan) cairan tebu. Dari satu pabrik dapat dihasilkan ampas tebu sekitar 35\% - 40\% dari berat tebu yang digiling. (Sumber dari tim penulis penebar swadaya, 1992 " pembudidayaan tebu di sawah dan tegalan " hal: 97 )

Mengingat begitu banyak limbah tersebut, maka ampas tebu akan memberikan nilai tambah tersendiri bagi pabrik gula bila diberi perlakuan lebih lanjut, karena sebagian besar ampas tebu di Negara Indonesia digunakan untuk bahan bakar pembangkit ketel uap pada pabrik gula dan bahan dasar pembuatan kertas.

Jerami merupakan hasil samping dari proses penggilingan padi. Ada beberapa masalah dalam penanganan jerami yang dihadapi oleh masyarakat petani. Pertama, bagaimana menggunakan jerami untuk mendapatkan keuntungan, dan kedua, apabila tidak terjual, bagaimana mengarangi kemungkinan terjadi polusi pada waktu pembuangan atau pembakaran.

Diperkirakan saat ini sebagian besar jerami sisa penggilingan padi tidak dipakai atau dibakar karena penggunaan jerami di Indonesia masih sebatas pada beberapa hal seperti digunakan alas untuk ternak, kompos, dan media pertumbuhan jamur, sedangkan produksi padi di Indonesia termasuk melimpah .

Disisi lain, Indonesia banyak terdapat jenis batubara yang belum dimanfaatkan secara maksimal. Dari kenyataan diatas, maka dapat dilihat adanya peluang untuk menggabungkan tiga hal tersebut, sehingga akan didapat suatu bahan bakar alternatif berupa Biobriket.

Masalah yang dibahas dalam tulisan ini adalah karakterisasi pembakaran biobriket berbahan dasar campuran antara batubara, jerami, dan ampas tebu. Dengan tiga variasi perbandingan pembuatan briket:

a. Batubara dicampur jerami dan ampas tebu, dengan perbandingan massa 10\% : 45\% : 45\%

b. Batubara dicampur jerami dan ampas tebu, dengan perbandingan massa $33,3 \%: 33,3 \%: 33,3 \%$

c. Batubara dicampur jerami dan ampas tebu, dengan perbandingan massa 50\% : 25\% : 25\%.

\section{TINJAUAN PUSTAKA}

Tahapan dalam pembakaran bahan bakar padat adalah sebagai berikut :

1. Pengeringan

Dalam proses ini bahan bakar mengalami proses kenaikan temperatur yang akan mengakibatkan menguapnya kadar air yang berada pada permukaan bahan bakar tersebut, sedangkan untuk kadar air yang berada di dalam akan menguap melalui pori-pori bahan bakar padat tersebut.

2. Devolatilisasi

Devolatilisasi yaitu proses bahan bakar mulai mengalami dekomposisi setelah terjadi pengeringan.

3. Pembakaran Arang

Sisa dari pirolisis adalah arang (fix carbon) dan sedikit abu, kemudian partikel bahan bakar mengalami tahapan oksidasi arang yang memerlukan 70\%$80 \%$ dari total waktu pembakaran.

Faktor-faktor yang mempengaruhi pembakaran bahan bakar padat, antara lain :

1. Ukuran partikel 
Partikel yang lebih kecil ukurannya akan lebih cepat terbakar.

2. Kecepatan aliran udara Laju pembakaran biobriket akan naik dengan adanya kenaikan kecepatan aliran udara dan kenaikan temperatur

3. Jenis bahan bakar

Jenis bahan bakar akan menentukan karakteristik bahan bakar. Karakteristik tersebut antara lain kandungan volatile matter dan kandungan moisture.

4. Temperatur udara pembakaran

Kenaikan temperatur udara pembakaran menyebabkan semakin pendeknya waktu pembakaran.

Beberapa masalah yang berhubungan dengan pembakaran biomass dengan batubara antara lain :

- Kadar air

Kandungan air yang tinggi menyulit kan penyalaan dan mengurangitemp eratur pembakaran.

- Kadar kalori

Semakin besar nilai kalor maka kecepatan pembakaran semakin lambat.

- Kadar abu
Kadar abu yang tinggi didalam batubara tidak mempengaruhi proses pembakaran. Kadar abu yang tinggi di dalam batubara akan mempersulit penyalaan batubara.

- Volatile matter atau zat-zat yang mudah menguap

Semakin banyak kandungan volatile matter pada biobriket maka semakin mudah biobriket untuk terbakar dan menyala.

- Bulk density

Ampas tebu dan jerami mempunyai bulk density yang jauh lebih rendah dibandingkan batubara.

\section{Jenis Polutan Yang Dihasilkan Pada Pembakaran Bahan Bakar}

Secara teoritis pembakaran bahan bakar menghasilkan $\mathrm{CO}_{2}$ dan $\mathrm{H}_{2} \mathrm{O}$ saja, padahal kenyataannya pembakaran pada bahan bakar banyak yang tidak sempurna dimana akan menimbulkan zat-zat polutan yang berbahaya terhadap kesehatan manusia. Adapun beberapa polutan dari bahan bakar antara lain : sulfur dioksida $\left(\mathrm{SO}_{\mathrm{x}}\right)$, carbon monoksida (CO), oksida nitrogen $\left(\mathrm{NO}_{\mathrm{x}}\right)$, oksidan $\left(\mathrm{O}_{3}\right)$, hidrokarbon (HC), khlorin ( $\mathrm{Cl}_{2}$ ), partikel debu, timah hitam $(\mathrm{Pb})$, besi (Fe). 


\section{METODOLOGI PENELITIAN}

\section{Diagram alir penelitian}

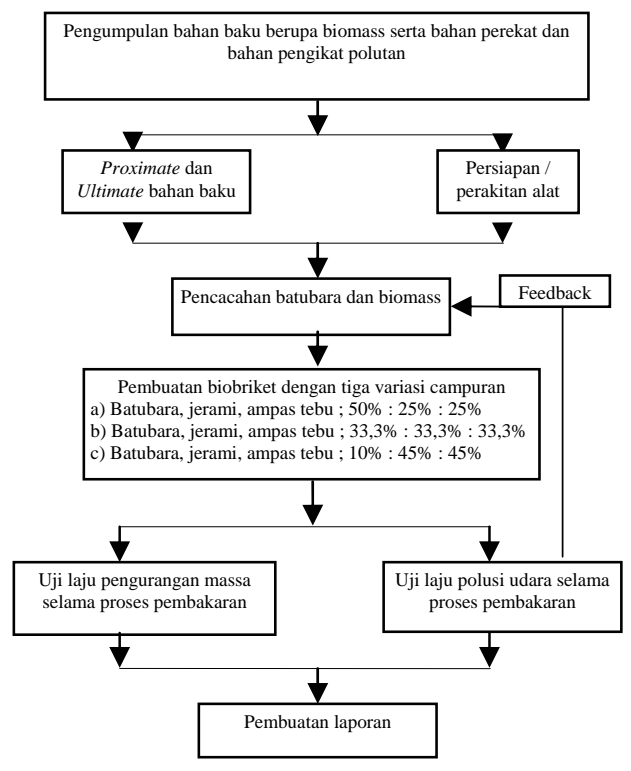

Gambar 1. Flowchart penelitian

\section{Pengumpulan dan Pengolahan Bahan}

Baku

1. Bahan Penelitian

- Batubara kualitas rendah (lignite) yang masih asli dan belum mengalami proses pengolahan.

- Ampas tebu dan jerami.

- Bahan perekat tepung kanji.

- Batu kapur (limestone) sebagai pengikat polutan

- Gas LPG, bahan bakar untuk memanaskan tungku pada pembakaran biobriket.

2. Pengolahan Bahan Baku

- Penghalusan batubara menjadi serbuk

- Pencacahan ampas tebu dan jerami menjadi serbuk

- Pembuatan bahan perekat

\section{Pembuatan Biobriket}

- Pencampuran bahan baku

Batu bara, ampas tebu, jerami, bahan perekat dan batu kapur dicampur hingga rata dengan komposisi batu bara : biomass = 10\% : 90\%, 33,3\% : 66,6\%, 50\% : $50 \%$. (dalam penelitian ini prosentase bahan perekat dan limestone diabaikan dan dianggap homogen ).

- Pencetakan biobriket

Bahan baku yang telah tercampur rata dimasukkan ke dalam cetakan yang berbentuk silinder dengan diameter 1,5 cm dan tinggi 2,2 cm.

- Pengepresan

Bahan baku dimasukkan ke dalam cetakan, kemudian dilakukan pengepresan dengan tekanan 100 $\mathrm{kg} / \mathrm{cm}^{2}$ dan didiamkan selama 10 menit. Setelah itu biobriket dikeluarkan dari cetakan dan dikeringkan di tempat yang tidakterkena sinar matahari secara langsung selama 3 hari.

Adapun biobriket yang dihasilkan dapat dilihat pada gambar2 


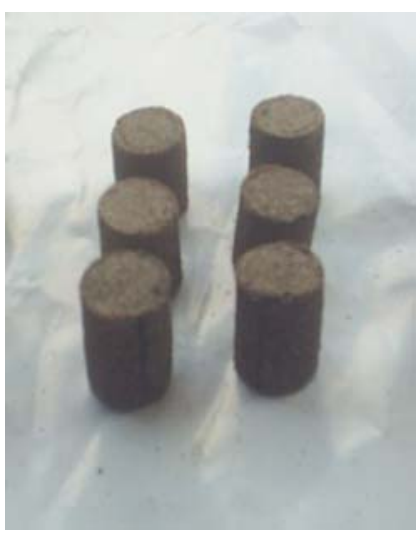

Gambar 2. Biobriket

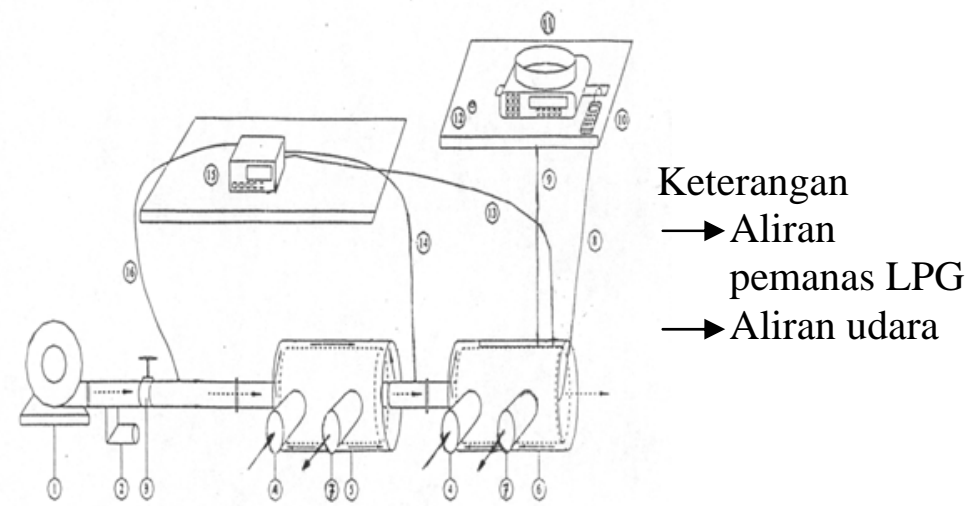

Gambar 3. Sketsa alat uji

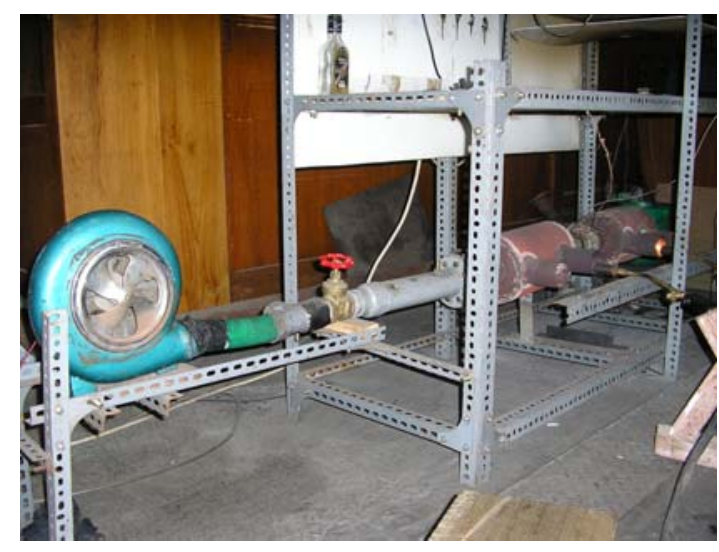

Gambar 4. Tempat pembakaran biobriket

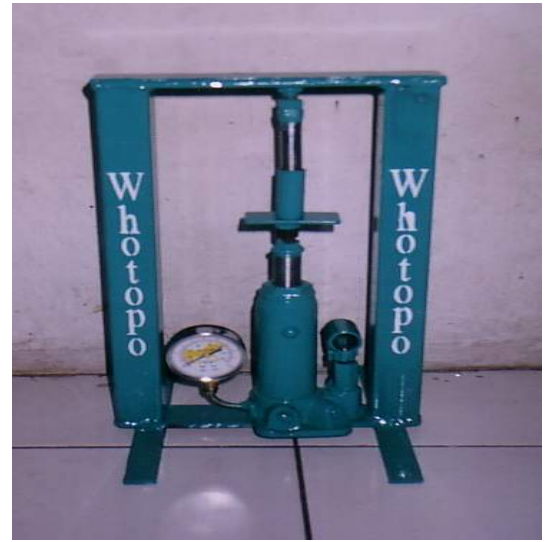

Gambar 5. Alat pengepress biobriket

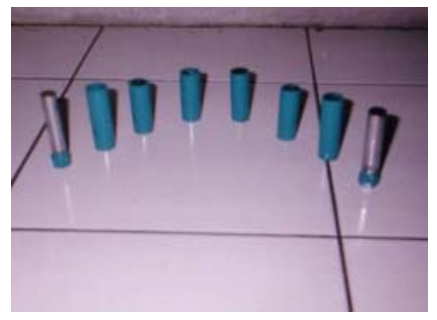

\section{Gambar 6. Cetakan biobriket}

\section{Peralatan Yang Digunakan}

Peralatan utama yang digunakan dalam penelitian ini terdapat di Laboratorium
Teknik Mesin Universitas Gajah Mada Yogyakarata :

a. Alat Pembakaran Biobriket 
Keterangan pada gambar 3 :

1. Blower

2. Saluran by pass

3. Katup pengatur aliran udara

4. Saluran masuk pemanas LPG

5. Tungku 1

6. Tungku 2

7. Saluran buang pemanas LPG

8. Termokopel temperatur dinding

9. Kawat penggantung sampel bahan bakar
10. Digital thermocouple reader

11. Electronic professional scale

12. Stop wacth

13. Termokopel temperatur gas pembakaran

14. Termokopel temperatur udara preheater

15. Digital thermocouple reader

16. Termokopel temperatur udara supply

b. Alat Pengepress biobriket.

\section{HASIL DAN PEMBAHASAN}

Sifat - sifat bahan dasar

Tabel 1. Sifat-Sifat Bahan Dasar

\begin{tabular}{|l|c|c|c|}
\hline \multicolumn{1}{|c|}{ Sifat } & Batubara & Ampas tebu & Jerami \\
\hline Kadar air (\%) & 14,31 & 21,18 & 12.7 \\
\hline Kadar abu (\%) & 2,02 & 2,67 & 18.48 \\
\hline Kadar kabon (\%) & 69,53 & 3,5 & 2.71 \\
\hline Volatile matter (\%) & 14,14 & 72,65 & 66.35 \\
\hline Nilai kalor (kal/kg) & 5289,395 & 3596,98 & 3456,48 \\
\hline
\end{tabular}

Tabel 2. Polutan Pada Pembakaran Biobriket

\begin{tabular}{|l|c|c|}
\hline \multirow{2}{*}{ Komposisi Briket } & \multicolumn{2}{|c|}{ Jenis polutan } \\
\cline { 2 - 3 } & HC (\% vol) & CO (\% vol) \\
\hline Batubara 10\% : Biomass 90\% & 0,0013 & 0,0031 \\
\hline Batubara 33.3\% : Biomass 66,6\% & 0,0014 & 0,0037 \\
\hline Batubara 50\% : Biomass 50\% & & 0,0042 \\
\hline
\end{tabular}

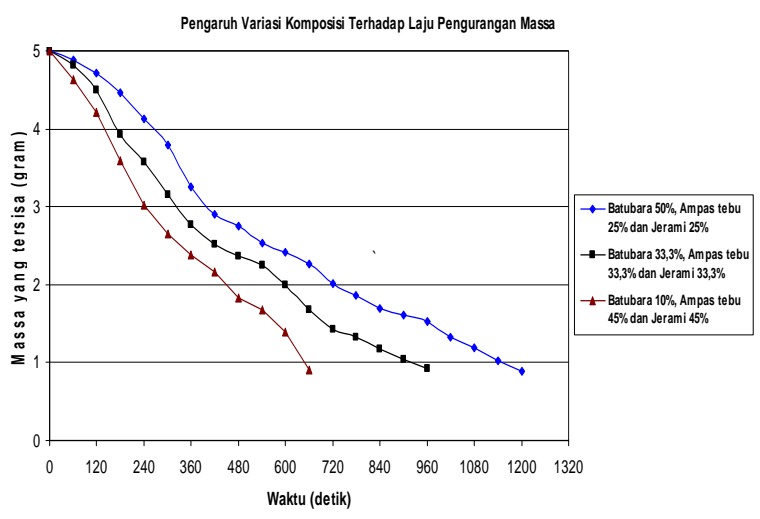

Gambar 7. Grafik laju pengurangan masa

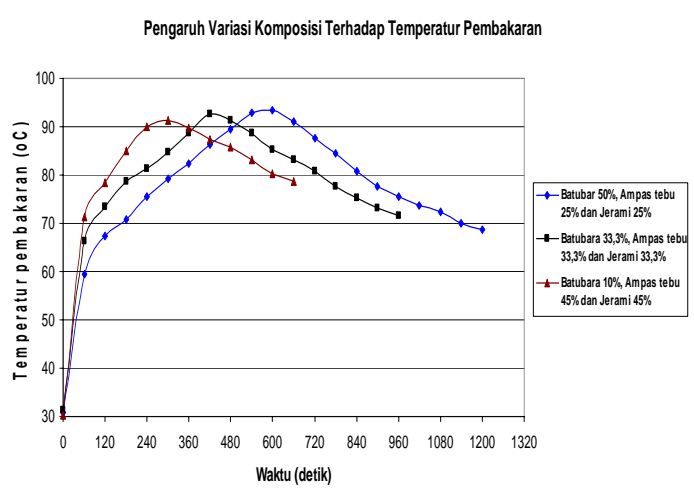

Gambar 8. Tempeatur pembakaran 
Grafik Pengaruh Variasi Komposisi Terhadap Laju Pengurangan Massa Pada Pembakaran Biobriket (Batubara : Biomass $=10 \%: 90 \%, 33,3 \%: 66,6 \%$, $50 \%: 50 \%$ )

Analisa yang didapat adalah, dari gambar 7 dan gambar 8 dapat dilihat bahwa laju pembakaran dari masing-masing biobriket tidaklah sama. Pembakaran paling cepat terjadi pada biobriket campuran batubara $10 \%$ : biomass $90 \%$, dari titik 0 detik grafik terus meningkat tajam sampai dengan titik maksimal yaitu 240 detik dengan laju pembakaran 0.00991 gram/detik, kemudian turun drastis di titik 360 detik. hal ini dipengaruhi oleh kandungan volatile matter di dalam biobriket, semakin banyak kandungan volatile matter maka semakin mudah dan cepat untuk terbakar. Namun terjadi fenomena lain dimana grafik laju pembakaran biobriket yang seharusnya terus menurun tetapi kembali naik, walaupun kenaikan tersebut tidak terlalu signifikan. Ini terjadi karena kondisi fisik dari biobriket itu sendiri pada saat pengujian yang tidak terbakar secara merata karena laju udara yang diberikan hanya mengenai sebagian dari sisi biobriket.

Sedangkan grafik untuk biobriket campuran batubara 33,3\% dan 50\%, kecepatan pembakarannya lebih lambat dibandingkan biobriket dengan campuran batubara yang hanya 10\%. Namun laju pembakaran biobriket tersebut menjadi lebih lama seiring dengan bertambahnya kandungan batubara di dalam biobriket, semakin banyak batubara maka semakin lama laju pembakarannya. Hal ini terjadi karena semakin sedikitnya kadar volatile matter yang dikandung biobriket tersebut.

Grafik Pengaruh Variasi Komposisi Terhadap Temperatur Pembakaran Pada Pembakaran Biobriket (Batubara : Biomass $=10 \%: 90 \%, 33,3 \%: 66,6 \%$, $50 \%: 50 \%$ )
Dari gambar 8 dapat dilihat bahwa temperatur pembakaran tertinggi terjadi pada proses pembakaran biobriket dengan komposisi 50\% biomass : 50\% batubara, terlihat dari titik awal temperatur $40,7^{\circ} \mathrm{C}$ di 0 detik grafik mulai naik tajam di titik temperatur $69,4^{\circ} \mathrm{C}$ hanya dengan selang waktu 60 detik. Kemudian grafik meningkat lagi menuju titik maksimum di $101.7^{\circ} \mathrm{C}$ dengan selang waktu 540 detik. Setelah mencapai temperatur tertinggi, pada umumnya suatu pembakaran biobriket akan mengalami penurunan temperatur seiring dengan menyusutnya massa biobriket, dan itu terbukti pada grafik diatas.

Hal yang membedakan dari grafik pada gambar 8 adalah kecepatan dari masingmasing biobriket untuk mencapai temperatur tertinggi, hal ini dipengaruhi oleh kandungan volatile matter dan nilai kalor di dalam biobriket. Semakin banyak kandungan nilai kalor maka semakin tinggi suhu maksimalnya, selain itu semakin sedikit kandungan volatile matter maka laju pembakaran akan bertahan lebih lama.

\section{Polutan Pada Pembakaran}

Dari table 2 terlihat bahwa polusi CO sangat dipengaruhi oleh kandungan $\mathrm{C}$ (karbon) dalam bahan dasar penyusun briket, semakin besar prosentase biomass pada biobriket maka kandungan emisi polutan CO akan semakin berkurang. Sedangkan untuk polusi HC paling rendah juga dihasilkan dari variasi campuran yang menggunakan prosentase batubara paling rendah.

\section{KESIMPULAN}

1. Laju pembakaran biobriket paling cepat adalah pada komposisi biomass 90\% : batubara $10 \%$. Hal ini dipengaruhi oleh kandungan volatile matter. Semakin banyak kandungan volatile matter suatu biobriket maka semakin mudah 
2. biobriket tersebut terbakar, sehingga laju pembakaran semakin cepat.

3. Biobriket dengan tingkat polusi terendah adalah pada komposisi biomass $90 \%$ : batubara $10 \%$, semakin

4. sedikit kandungan batubara suatu biobriket maka semakin sedikit polutan CO yang dihasilkan, karena semakin sedikitnya karbon yang bereaksi dengan oksigen pada saat pembakaran, dan semakin banyak kandungan biomass pada biobriket akan menurunkan emisi polutan HC.

5. Penggunaan biobriket untuk kebutuhan sehari-hari sebaiknya digunakan biobriket dengan perbandingan komposisi biomass 90\% : batubara $10 \%$, karena tingkat polusinya paling rendah dan pencapaian suhu maksimal paling cepat .

\section{DAFTAR PUSTAKA}

Antolin, G., Velasco,E.,Irusta,R.,Segovia,J.J.,1991, Combustion of Coffe Lignocellulose Waste, Proceedings of First Internasional Conference, Vilamoura, Portugal.

Archie, W. Culp. Jr,1984, Principle of Energy Conversion, Missouri-Rolla

Damardjati, D.S., 1991, Pusat penelitian dan pengembangan tanaman pangan, IPB, Bogor.

Fastabiqul Khoerot., 2005, Pengaruh Tekanan Terhadap Laju Pembakaran Dan Temperatur Pembakaran Biobricket (campuran sabut kelapa dan batubara) dengan variasi tekanan $50 \mathrm{~kg} / \mathrm{cm}^{2}, 75 \mathrm{~kg} / \mathrm{cm}^{2}$ dan $100 \mathrm{~kg} / \mathrm{cm}^{2}$. Tugas Akhir, FT UMS.

Himawanto, D.A., 2003, Pengolahan Limbah Pertanian menjadi Biobriket sebagai salah satu Bahan Bakar Alternatif. Penelitian UNS.

Joko, S., 2005, Pengolahan Sampah Kota menjadi biobriket sebagai salah satu bahan bakar alternative, Tugas Akhir, FT UMS.

Naruse,I.,Gani,A.,Morishita,K.,2001,Fundamental Characteristic on Co-Combustion of Low Rank Coal with Biomass, Pittsburg.

Sudradjat, R., 2001, The Potensial of Biomass Energy Resources in Indonesia for the Possible Development of Clean Technology Process (CPT), Jakarta .

Sukandarumidi, 1995, Batubara dan gambut, UGM Pres.

Samsul, M., 2004, Pengaruh Penambahan Arang Tempurung Kelapa Dan Penggunaan Perekat Terhadap Sifat-Sifat Fisika Dan Kimia Briket Arang Dari Arang serbuk Kayu Sengon, UGM. 